\title{
Perancangan Aplikasi Perekrutan Karyawan Berbasis Web Menggunakan Platform Pega
}

\author{
Trivena Andriani ${ }^{1)}$, Hindriyanto Dwi Purnomo ${ }^{2)}$ \\ ${ }^{1,2)}$ Universitas Kristen Satya Wacana \\ Jl. Diponegoro No.52-60, Salatiga, Kec. Sidorejo, Kota Salatiga, Jawa Tengah 50711 \\ Email : trivenaandriani77@gmail.com
}

\begin{tabular}{ccc}
\hline Recieved: $12-08-2020$ & $\begin{array}{c}\text { Riwayat artikel: } \\
\text { Revised:05-02-2021 }\end{array}$ & Accepted:06-02-2021 \\
\hline
\end{tabular}

\section{Abstract}

Recruitment process is the management of prospective employee data. In this study, a web-based employee recruitment system is designed for data management of prospective employees. The process model used in this study is a prototype model. The platform used is Pega. This research uses a case study at PT. Sinar Mas Insurance. Based on the results of the tests carried out, it was found that the application made was easy to use and assisted in recruiting.

Keywords: Recruitment, Web, Pega

\begin{abstract}
Abstrak
Perekrutan karyawan merupakan proses penting untuk mendapatkan tenaga kerja yang berkualitas. Salah satu kendala yang dihadapi dalam proses perekretuan karyawan adala $h$ pengelolaan data calon karyawan. Dalam penelitian ini dirancang sistem perekrutan karyawan berbasis web untuk pengelolaan data calon karyawan. Model proses yang dipergunakan dalam penelitian ini adalah model prototype. Platform yang dipergunakan adalah Pega. Penelitian ini menggunakan studi kasus di PT. Asuransi Sinar Mas. Berdasarkan hasil pengujian yang dilakukan didapatkan bahwa aplikasi yang dibuat mudah untuk digunakan serta membantu dalam melakukan rekruitmen.
\end{abstract}

Kata kunci: Rekrutmen, Web, Pega

\section{Pendahuluan}

Sumber daya manusia yang berkualitas saat ini sangat dibutuhkan perusahaan. Oleh karena itu, perusahaan perlu melakukan upaya untuk mendapatkan tenaga kerja yang berkualitas. Proses untuk mendapatkan tenaga kerja yang berkualitas dimulai dari seleksi calon tenaga kerja. Untuk melakukan seleksi dengan baik. diperlukan informasi yang akurat terkait dengan profil calon tenaga kerja yang akan direkrut serta informasi kebutuhan tenaga kerja dari tiap divisi di perusahaan.

Perekrutan tenaga kerja di perusahaan umumnya dilakukan melalui satu pintu, yaitu bagian Human Resource Development (HRD). Oleh karena itu, HRD 
perlu menjalin komunikasi yang baik dengan semua divisi di perusahaan agar bisa menentukan calon tenaga kerja yang tepat sesuai kebutuhan tiap divisi. Proses menentukan calon yang sesuai kebutuhan tiap divisi merupakan sebuah tantangan bagi HRD. Salah satu kendala yang dihadapi adalah dalam hal pengelolaan data calon tenaga kerja. Pengolahan data yang masih manual serta belum terintegrasi secara online serta banyaknya jumlah calon tenaga kerja menyebabkan adanya penumpukan berkas dan potensi hilangnya berkas, sehingga pencarian data menjadi lama dan menghambat proses rekrutmen [1]. Efektifitas dan efisiensi untuk mendapatkan data tentang calon karyawan sangat penting bagi suatu perusahaan, sehingga dibutuhkan pemanfaatan suatu sistem atau aplikasi untuk mengelola data calon tenaga kerja [2]. Dengan adanya aplikasi pengelolaan data calon tenaga kerja diharapkan dapat membantu proses perekrutan karyawan baik dari proses pencarian berkas maupun meminimalkan hilangnya data. Selain itu, pengelolaan data secara online memungkinkan proses perekrutan calon tenaga kerja menjadi lebih mudah karena tidak harus dilakukan di kantor namun dapat dilakukan dimana saja dan kapan saja selama jaringan internet [3].

Dalam penelitian ini dilakukan perancangan aplikasi perekrutan karyawan yang memungkinkan HRD mencari informasi seputar calon karyawan mengenai data diri, divisi yang dilamar, IQ dan skill yang dimiliki calon karyawan tersebut. Pembangunan aplikasi ini menggunakan platform Pega karena sesuai dengan platform yang dipergunakan oleh perusahaan yang dijadikan studi kasus dalam penelitian ini. Penelitian ini menggunakan dengan studi kasus di PT Asuransi Sinar Mas.

\section{Kajian Pustaka}

Simamora[4] menyatakan bahwa Rekrutmen (Recruitment) adalah serangkaian aktivitas mencari dan memikat kandidat kerja dengan motivasi, kemampuan, keahlian dan pengetahuan yang diperlukan guna menutupi kekurangan yang diidentifikasi dalam perencanaan kepegawaian. Sehingga melalui proses rekrutmen yang ada akan didapatkan sumber daya manusia yang memenuhi kriteria perusahaan. Pengelolaan rekruitmen secara online merupakan sebuah kebutuhan. Umumnya pengelolaan online ini berbasiskan pada aplikasi web. Website dapat bersifat statis dan dinamis, web statis adalah web yang informasi di dalamnya tidak pernah berubah misalnya website perusahaan sedangkan web dinamis merupakan sebuah web yang dapat berubah sebagai contoh adalah media sosial [5].

Ada beberapa literatur terkait dengan pemanfaatan sistem rekrutmen antara lain rancangan sistem perekrutan karyawan secara online berbasis web untuk membantu staf HRD mendapatkan informasi seputar kandidat yang dibuat menggunakan metode System Development Life Cycle (SDLC) agar 
pengerjaannya dapat dilakukan secara berurutan dan model waterfall untuk meminimalkan kesalahan [6].

Penelitian yang dilakukan oleh [7] berpusat pada perancangan informasi perekrutan karyawan yang memanfaatkan internet atau biasa disebut $e$ recruitment yang diaplikasikan pada sebuah web sehingga mempermudah kandidat dan bagian HRD dalam melaksanakan proses rekrutmen yang bertujuan untuk mendapatkan calon karyawan yang potensial sesuai dengan kebutuhan perusahaan. Pembangunan web ini memakai metode waterfall di mana proses yang dilakukan satu per satu dibangun secara sistematis sehingga memudahkan pengembang dalam mengembangkan web ini. Pembangunan web menggunakan software XAMPP versi 1.7.3, My Structured Query Language (MYSQL) database, bahasa pemrograman Hypertext Preprocessor (PHP) pada Adobe Dreamweaver CS 5.5 untuk membangun aplikasinya, kemudian untuk memperindah tampilan menggunakan Adobe Photoshop CS3.

Penelitian [8] lain yang membahas tentang pembangunan aplikasi untuk menilai pertanggungan dan premi yang dibayarkan oleh nasabah menggunakan platform Pega yang bertujuan untuk mempercepat penerbitan polis. Aplikasi ini dipindahkan dari platform ASP ke Pega untuk memperbaiki kecepatan pencarian data dan user interface. Penggunaan platform Pega dinilai sangat efektif karena pada platform Pega dapat menerjemahkan proses bisnis menjadi aplikasi dan menggunakan function yang pernah dibuat sebelumnya sehingga mempercepat pembangunan aplikasi.

Dalam penelitian ini lebih menekankan pada aplikasi sistem perekrutan yang sesuai dengan kebutuhan di PT. Asuransi Sinar Mas, sehingga secara proses bisnis sistem ini akan berbeda dengan beberapa penelitian yang sudah dilakukan sebelumnya. Aplikasi dibuat menggunakan platform Pega. Pega merupakan sebuah perantara yang dipakai untuk menerjemahkan proses bisnis management menjadi sebuah aplikasi. Di dalam Pega sendiri terdapat sebuah proses alur kerja untuk membangun aplikasi yang biasanya berbentuk layanan web. Platform ini terdapat agile di mana agile merupakan sebuah metodologi dalam pembuatan software berdasarkan prinsip yang sama atau dalam mengembangkan sistem dengan waktu yang singkat yang perlu penyesuaian singkat pula dari pengembang atas perubahan apapun [9]. Beberapa instansi yang menggunakan Pega yaitu perbankan, perawatan kesehatan dan berbagai instansi lainnya yang membutuhkan aliran proses yang efisien. Pada platform Pega terdapat kerangka kerja yang siap pakai untuk membangun aplikasi. Pada pembangunan aplikasi di Pega sudah tersedia web service, Message Queue (MQ), Java DataBase Connection JDBC logic dan developer hanya membuat tampilan aplikasi dan beberapa fungsi yang belum tersedia di Pega [10]. 
Model proses yang dipergunakan dalam penelitian ini menggunakan model prototype. Model Prototype merupakan sebuah merupakan sebuah model untuk merancang aplikasi yang mempresentasikan aplikasi yang akan dibuat sesuai dengan kebutuhan user [11]. Tahapan model proses prototype meliputi requirements gathering di mana user dan developer bertemu untuk menganalisa kebutuhan aplikasi Job Fair baik fitur maupun tampilan seperti form untuk mengisi data karyawan dan psikotes. Tahap analysis merupakan tahap di mana developer akan memilah dari kebutuhan yang disebutkan oleh user apa saja yang dapat dikerjakan. Tahap perancangan aplikasi yang digambarkan dalam bentuk use case diagram untuk gambaran aplikasinya dan pembangunan aplikasi menggunakan platform Pega dengan bantuan IDE designer studio. Tahap pengujian aplikasi menggunakan metode black box dan user acceptance testing untuk menguji fungsionalitas dan tampilan yang sudah dibuat sesuai dengan kebutuhan user. Tahap validation atau kesesuaian aplikasi Job Fair dengan keinginan user jika fitur-fitur dan fungsionalitas sudah sesuai aplikasi siap untuk diimplementasikan. Apabila aplikasi belum sesuai dengan kebutuhan user maka aplikasi diperbaiki dan kembali ke tahap awal dengan lebih rinci karena sudah ada rancangan aplikasi yang dapat dijadikan acuan dalam langkah selanjutnya.

Rancangan aplikasi menggunakan use case diagram di mana use case menggambarkan sebuah hubungan antara aktor dengan sistem yang akan dibangun.

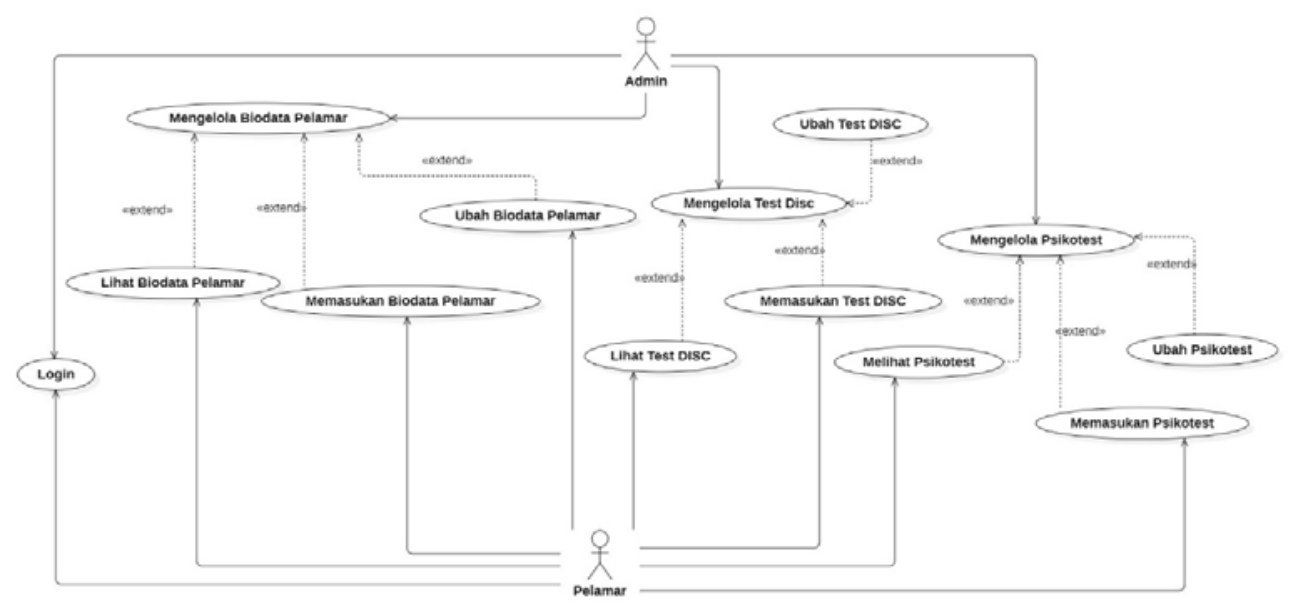

Gambar 1 Use case Diagram dari Aplikasi

Gambar 1 merupakan gambar use case dari JobFair, di mana terdapat hak akses dari masing-masing aktor. Aktor Admin memiliki hak akses untuk mengelola data diri kandidat, mengelola tes Dominance, Influence, Steadiness, Compliance (DISC) yang merupakan sejumlah pernyataan yang harus dijawab kandidat untuk mengetahui tipe karakter kandidat [12]. Admin juga mengelola 
psikotes dengan fungsi create, read, update dan delete (CRUD). Aktor kandidat sendiri memiliki fungsi CRU pada mengelola biodata kandidat, akses create dan read pada mengelola tes DISC dan psikotes di mana kandidat hanya bisa membaca soal dan mengisi soal.

\section{Hasil dan Pembahasan}

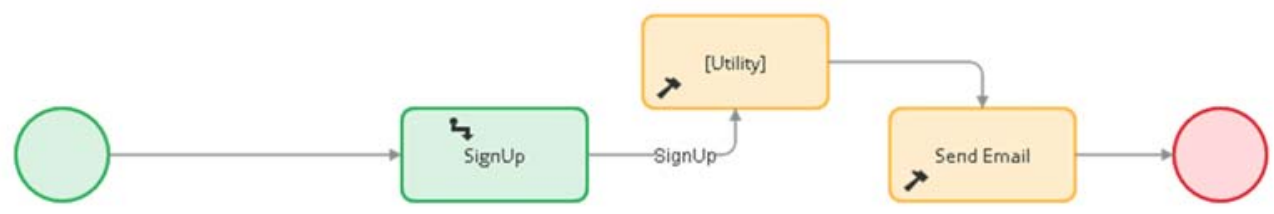

Gambar 1 Flow Registration

Gambar 2 merupakan flow untuk registrasi akun Job Fair untuk kandidat di mana kandidat harus mengisi form yang tersedia seperti Nomor Induk Kependudukan, nama, email dan password untuk login akun pada Job Fair dan aka nada email pemberitahuan mengenai username dan password kandidat.

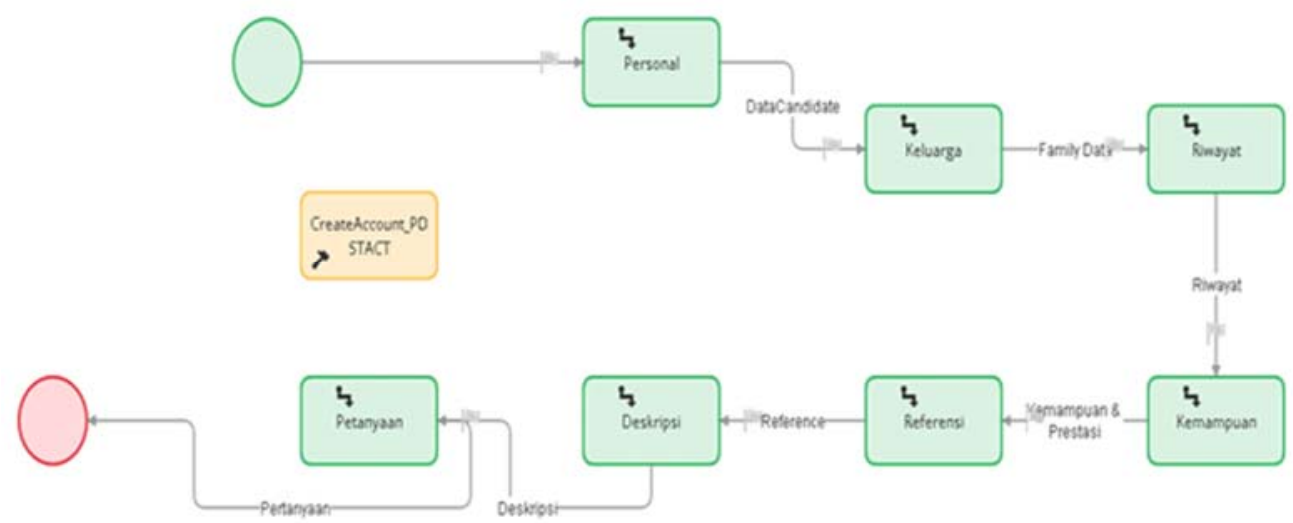

Gambar 3 Flow Collect Information

Gambar 3 merupakan alur kegiatan dari Flow Data Diri kandidat Job Fair di mana kandidat mengisi data diri kandidat, data keluarga, data riwayat pekerjaan, data kemampuan pelamar, data referensi, data deskripsi diri pelamar dan pertanyaan seputar kandidat ke form yang ada. Flow dimulai pada saat pelamar mengisikan data diri pelamar sampai dengan menjawab semua pertanyaan.

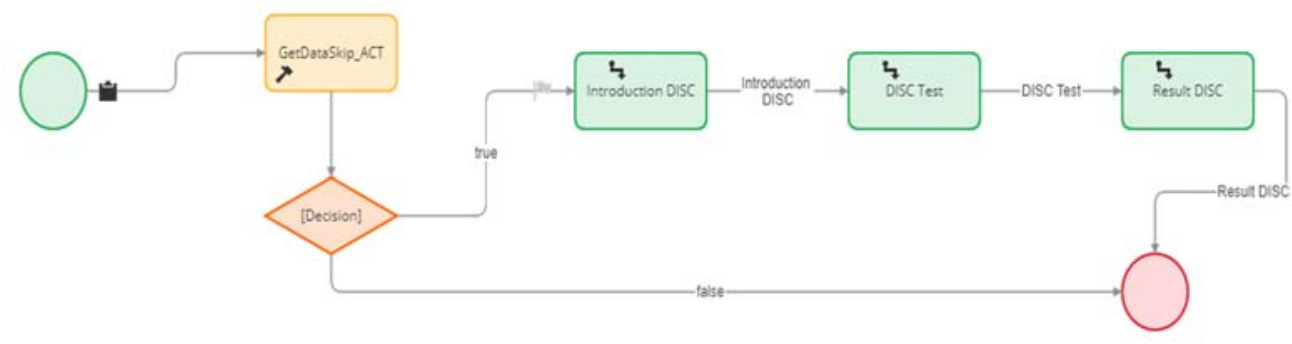

Gambar 4 Flow DISC Test 
Gambar 4 merupakan flow untuk tes DISC yang terdiri dari tiga assignment yang terdiri dari introduction DISC, DISC Test, Result DISC. Flow dimulai dari pengecekan data pelamar apabila data pelamar ada maka masuk ke assignment. Apabila tidak ada data pelamar maka proses akan langsung ke end process. Assignment bisa saling terhubung karena adanya connector.

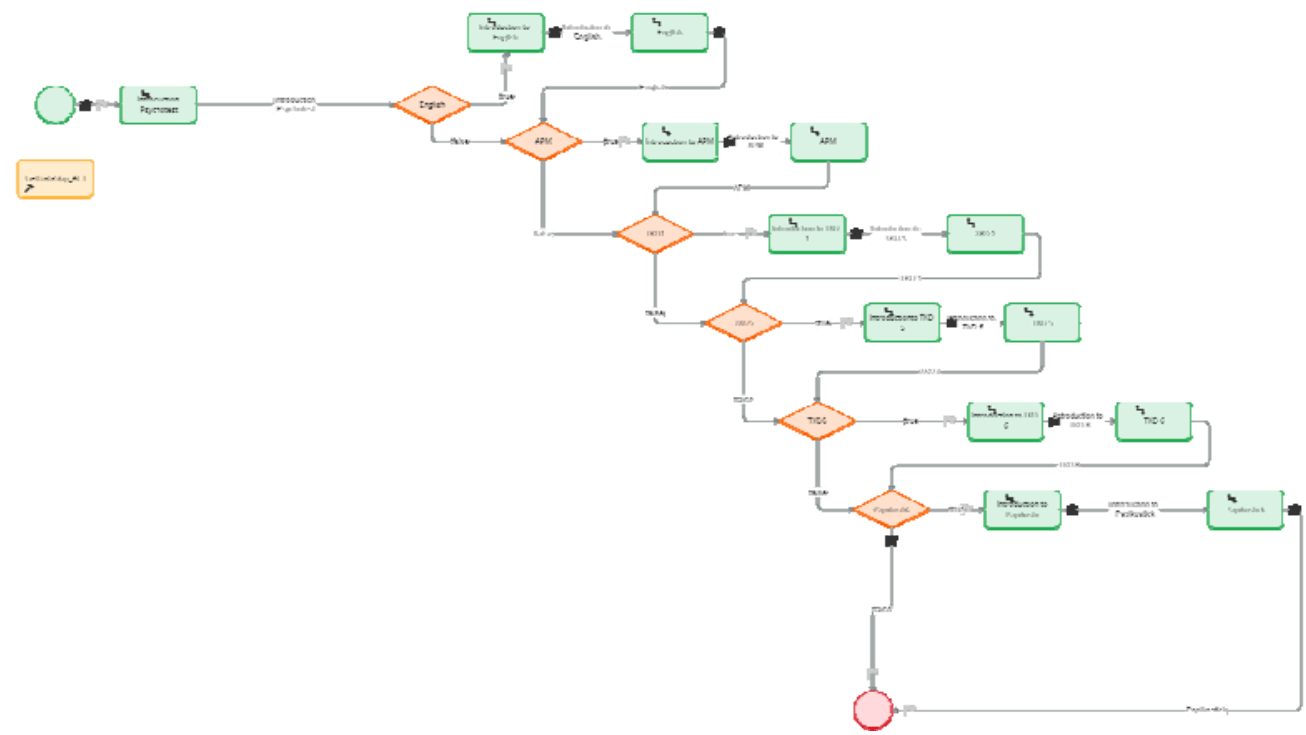

Gambar 5 Flow Psikotes

Gambar 5 merupakan gambar yang menunjukan flow psikotes yang akan dilalui kandidat. Ketika kandidat akan melakukan psikotes pada halaman muncul introduction psikotes di mana akan ada penjelasan tentang pengerjaan psikotes secara umum. Pada gambar ini ada beberapa decision karena kandidat hanya akan mendapatkan beberapa kategori psikotes yang ditentukan HCD sesuai dengan jabatan yang dilamar. Pada flow ini terdapat beberapa tes yaitu bahasa inggris, advance progressive matrices (APM) yang digunakan untuk menguji pola pikir kandidat terhadap permasalahan yang ada [13]. TKD yang berisi tentang kemampuan dasar dan PAPI-Kostick adalah tes untuk mengetahui kepribadian kandidat berdasarkan sudut pandang individu terhadap tes yang dilakukan kandidat [14].

Hasil penelitian yang dilakukan berupa aplikasi perekrutan karyawan pada PT. Asuransi Sinar Mas berbasis web untuk mendapatkan sumber daya manusia yang berkualitas. Pembangunan aplikasi ini menggunakan model prototyping. Aplikasi ini mempermudah perekrutan karyawan dari berbagai tempat karena dapat diakses ketika ada koneksi internet. 


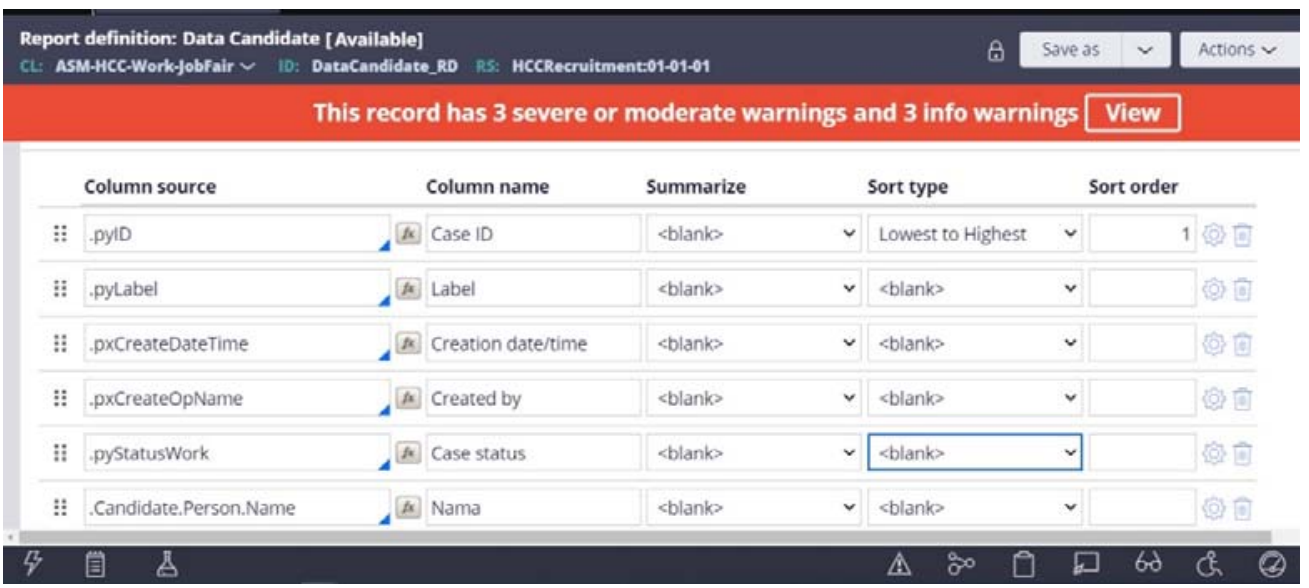

Gambar 6 Report Definition Job Fair

Gambar 6 merupakan contoh report definition yang berfungsi untuk menyimpan data yang telah dimasukkan user ke dalam database di Pega. Data disimpan dalam property, property dalam report definition merupakan kolom dalam database. Untuk membuat function yang sederhana di Pega dapat menggunakan Data Transform. Data transform berisi method yang ada pada Pega, yang terdiri dari action yaitu memberikan kondisi ke property yang akan dituju yang terdapat pada kolom target. Kolom relation menggambarkan hubungan antar target dan source yang merupakan property yang dituju. Contoh data transform terdapat pada gambar 7 .

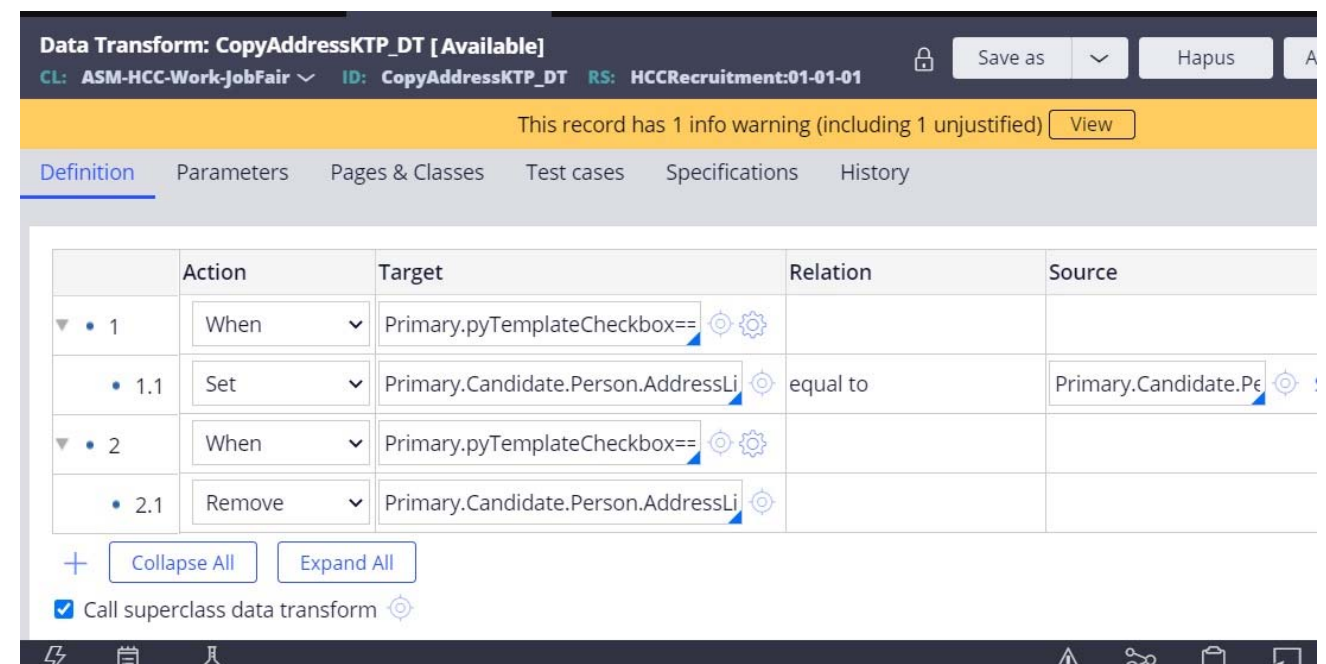

Gambar 7 Data Transform Copy Address

Selain menggunakan data transform Pega menyediakan activity yang dapat digunakan untuk membuat sebuah function. Activity ini terdiri dari langkah yang berurutan terdiri dari beberapa method. 
AITI: Jurnal Teknologi Informasi

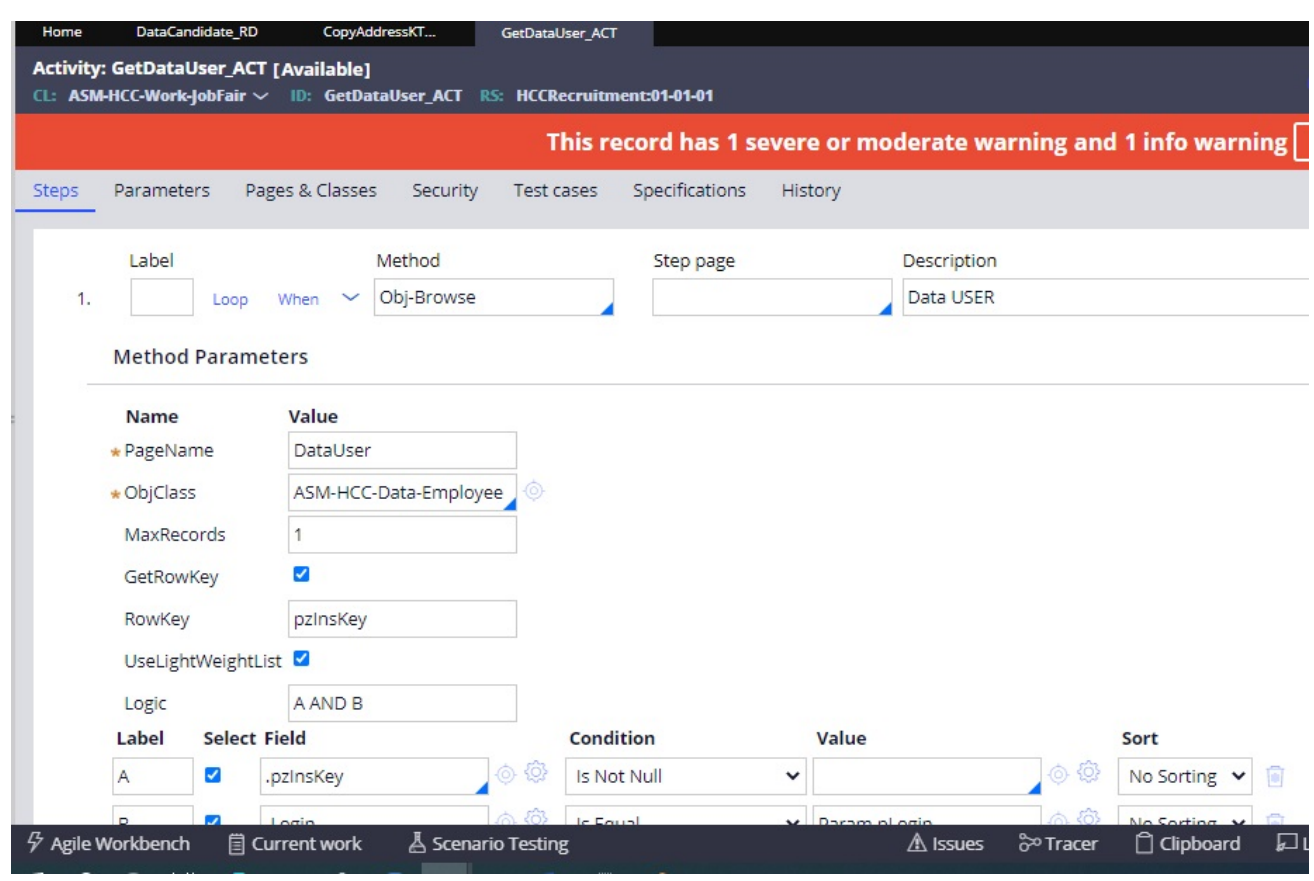

Gambar 8 Activity Get Data User

Activity pada gambar 8 merupakan contoh function untuk mengambil data kandidat yang sudah selesai melakukan proses rekrutmen. Salah satu method yang digunakan adalah Obj-Browse untuk mendapatkan data dari sebuah class data yang ada. Program dimulai pada saat kandidat melakukan registrasi akun kandidat yang terdapat pada gambar 9 .

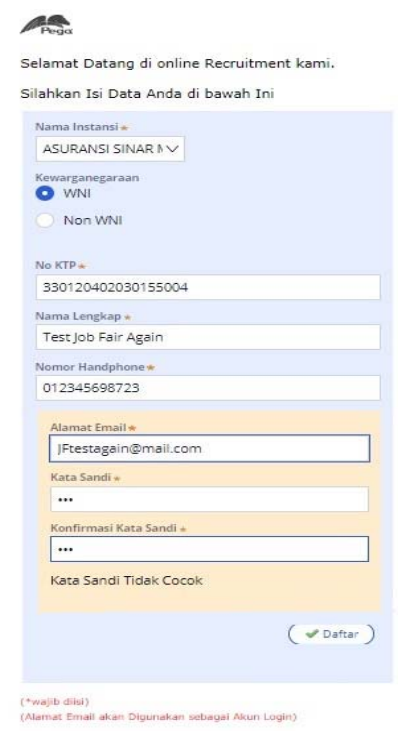

Gambar 9 Halaman Registrasi 
Pada halaman ini user membuat akun dengan memasukkan beberapa data yaitu perusahaan yang akan dilamar, kewarganegaraan kandidat, nomor kartu identitas, nama lengkap, email dan password. Akun yang sudah dibuat dapat digunakan untuk login pada aplikasi Pega seperti gambar 10.

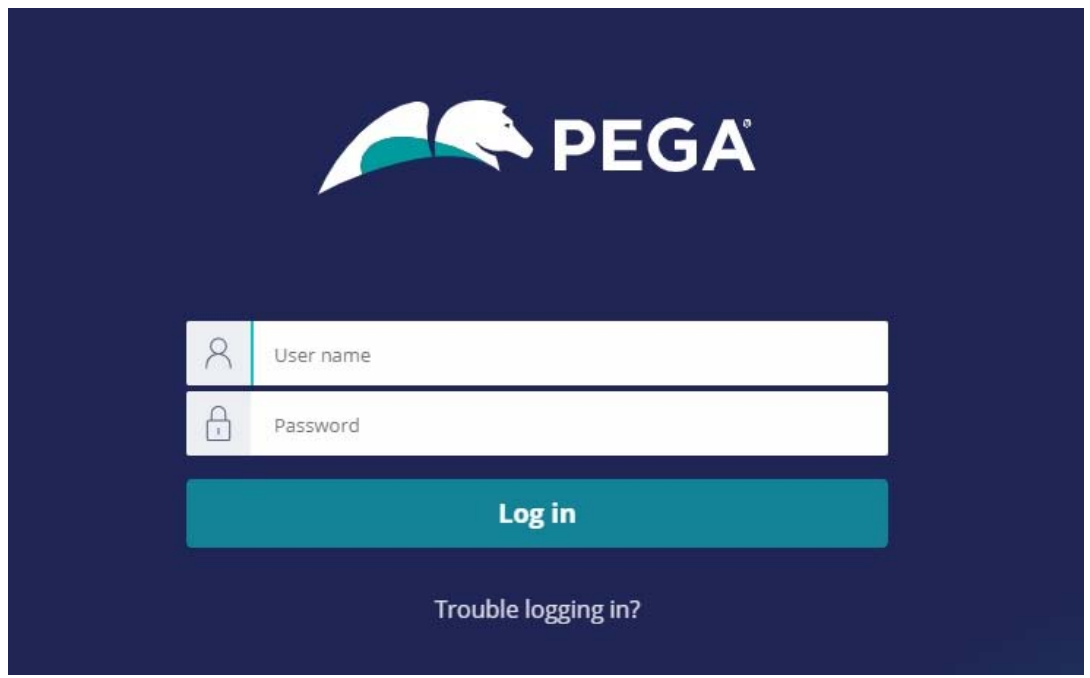

Gambar 10 Halaman Login

Pada halaman ini user memasukkan username dan password, kemudian Aplikasi akan memproses masukan dari user dengan melakukan pencocokan dengan database, jika username dan valid password maka aplikasi akan mengaktifkan session dan mengalihkan ke halaman awal aplikasi Job Fair. Form pada gambar 11 merupakan form yang diminta pada kandidat untuk mengisi biodata seputar kandidat sesuai dengan identitas kandidat.

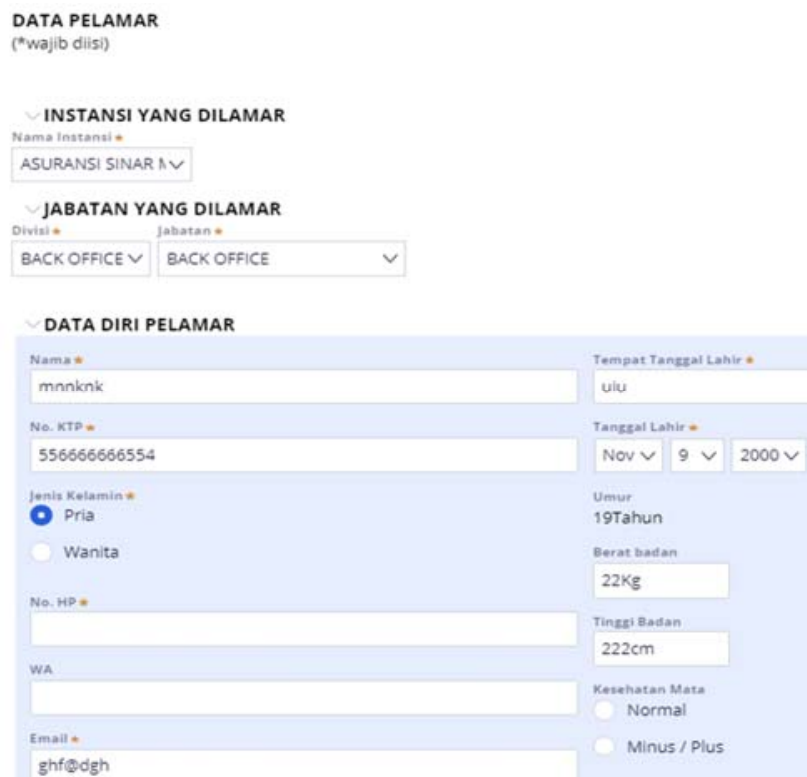

Gambar 11 Form untuk biodata kandidat 
Kandidat yang sudah selesai mengisi data diri dapat menuju ke psikotes. Kategori psikotes pertama yaitu DISC seperti gambar 12.

Test DISC Pelamar

\section{$1 / 24$}

$\begin{array}{lll}\text { Sesuai } & \text { Tidak Sesuai } & \\ \text { O 1 } & 01 & \text { Menjadi frustasi } \\ 2 & 2 & \text { Menyimpan perasaan saya } \\ 3 & 03 & \text { Menceritakan sisi saya } \\ 4 & 4 & \text { Siap beroposisi }\end{array}$

Gambar 12 Tampilan tes DISC

Gambar 12 merupakan tampilan saat kandidat melakukan tes DISC yaitu tes yang menggambarkan tentang kepribadian kandidat. Kategori psikotes selanjutnya yaitu APM seperti pada gambar 13 .

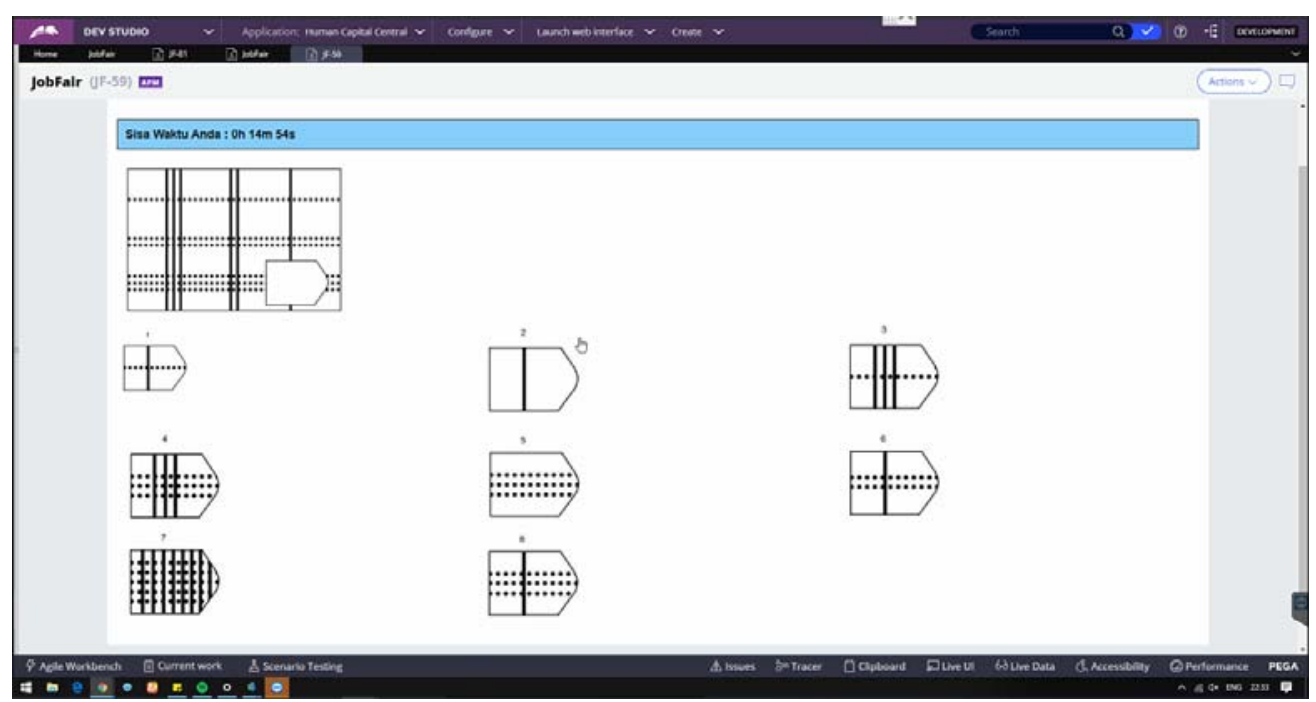

Gambar 13 Tampilan soal APM

Gambar 13 merupakan salah satu tampilan soal psikotes kategori APM untuk kandidat. Tes APM merupakan tes yang berisi tentang pola gambar di mana peserta harus menentukan pola yang sesuai pada bagian yang kosong. Proses rekrutmen dari pengisian data diri sampai psikotes, data tersimpan ke dalam record seperti pada gambar 14 . 


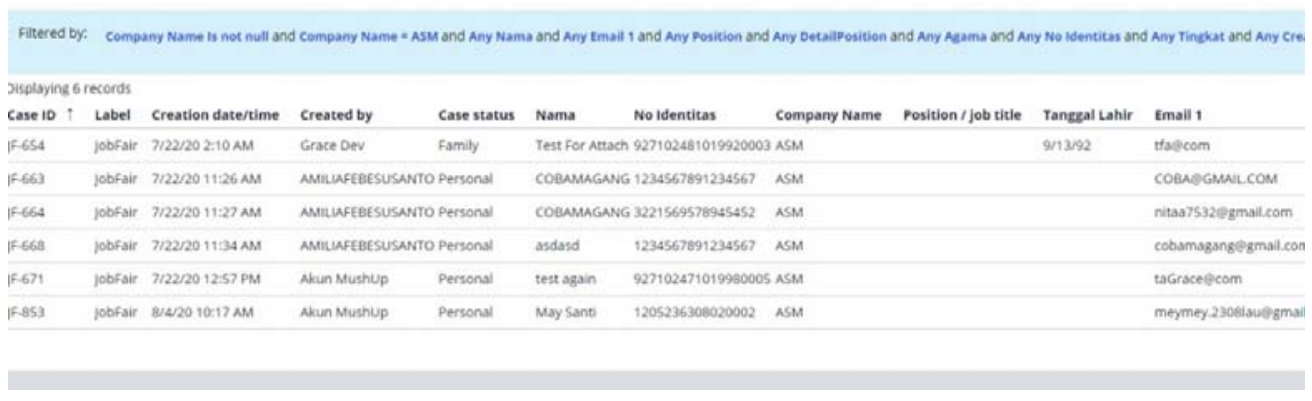

Gambar 14 Record Data Job Fair

Gambar 14 merupakan record data Job Fair, di mana record merupakan data yang tersimpan dalam report definition dan yang tersimpan dalam database.

Aplikasi ini dapat membantu menyimpan data kandidat yang mengikuti proses rekrutmen dari berbagai daerah sehingga mempermudah untuk mendapatkan dan menyimpan data kandidat untuk dinilai oleh staf HCD sesuai dengan proses bisnis yang ada. Aplikasi ini juga dapat membantu mengurangi penggunaan kertas di perusahaan karena data kandidat langsung masuk ke dalam database sehingga pengeluaran biaya perusahaan untuk proses rekrutmen berkurang. Data yang tersimpan nantinya dapat diolah untuk keperluan penilaian karyawan, memperbarui data karyawan, proses gaji karyawan dan kebutuhan perusahaan lainnya. Kendala yang ditemukan saat pembangunan aplikasi ini adalah load data belum cepat dan server Pega yang sering restart menghambat pembangunan aplikasi.

\section{Pengujian Aplikasi}

Pengujian aplikasi dilakukan untuk mengevaluasi aplikasi yang telah dibuat untuk mengetahui kekurangan dari aplikasi. Pengujian ini dilakukan dengan teknik pengujian black box testing dan user acceptance testing. Black box testing berfungsi untuk menguji fungsionalitas sistem.

Tabel 1. Black Box Testing

\begin{tabular}{|c|c|c|c|c|}
\hline MENU & Input/Case & $\begin{array}{l}\text { Output Yang } \\
\text { Diharapkan }\end{array}$ & $\begin{array}{l}\text { Output yang } \\
\text { Dihasilkan }\end{array}$ & Status \\
\hline $\begin{array}{l}\text { Login } \\
\text { Kandidat }\end{array}$ & $\begin{array}{l}\text { Pengisian } \\
\text { username dan } \\
\text { password valid }\end{array}$ & Login berhasil & Login berhasil & Valid \\
\hline Data Diri & $\begin{array}{l}\text { Pengisian data } \\
\text { diri kandidat }\end{array}$ & $\begin{array}{l}\text { Berhasil } \\
\text { dimasukkan }\end{array}$ & $\begin{array}{l}\text { Berhasil } \\
\text { dimasukkan }\end{array}$ & Valid \\
\hline $\begin{array}{l}\text { Data } \\
\text { Keluarga }\end{array}$ & $\begin{array}{l}\text { Pengisian data } \\
\text { keluarga dan } \\
\text { Form status } \\
\text { cerai hidup, } \\
\text { cera mati dan } \\
\text { sudah tanggal } \\
\text { yang tidak }\end{array}$ & Inputan berhasil & Inputan berhasil & Valid \\
\hline
\end{tabular}


boleh lebih dari

hari ini

\begin{tabular}{|c|c|c|c|c|}
\hline $\begin{array}{l}\text { Data } \\
\text { Riwayat } \\
\text { Kandidat }\end{array}$ & $\begin{array}{l}\text { Pengisian data } \\
\text { riwayat } \\
\text { pendidikan, } \\
\text { pekerjaan dan } \\
\text { organisasi }\end{array}$ & Inputan berhasil & Inputan berhasil & Valid \\
\hline $\begin{array}{l}\text { Pertanyaan } \\
\text { riwayat } \\
\text { kandidat }\end{array}$ & $\begin{array}{l}\text { Pertanyaan } \\
\text { tentang riwayat } \\
\text { kandidat } \\
\text { dengan } \\
\text { jawaban IYA } \\
\text { dan TIDAK }\end{array}$ & $\begin{array}{l}\text { Ketika jawaban } \\
\text { YA maka akan } \\
\text { muncul text area, } \\
\text { ketika jawaban } \\
\text { TIDAK tidak } \\
\text { muncul apapun }\end{array}$ & $\begin{array}{l}\text { Ketika jawaban } \\
\text { YA maka akan } \\
\text { muncul text area, } \\
\text { ketika jawaban } \\
\text { TIDAK tidak } \\
\text { muncul apapun }\end{array}$ & Valid \\
\hline Psikotes & $\begin{array}{l}\text { Pertanyaan } \\
\text { muncul sesuai } \\
\text { urutan kategori } \\
\text { psikotes }\end{array}$ & $\begin{array}{l}\text { Kandidat dapat } \\
\text { mengisi jawaban }\end{array}$ & $\begin{array}{l}\text { Kandidat dapat } \\
\text { mengisi jawaban }\end{array}$ & Valid \\
\hline
\end{tabular}

Berdasarkan black box testing yang dilakukan oleh tim developer dapat disimpulkan bahwa menu utama dapat berjalan dengan baik sesuai dengan kebutuhan user. User Acceptance Testing (UAT) yang dilakukan pada oenelitian ini melibatkan 5 responden dan 5 pertanyaan yang dihitung menggunakan skala likert. 5 responden yang ada terdiri dari 3 responden dari divisi HCD dan 2 responden dari divisi IT. Hasil pengujian digunakan sebagai bukti bahwa aplikasi siap digunakan oleh user.

Tabel 2. Tabel User Acceptance Testing

\begin{tabular}{|c|c|c|c|c|c|c|}
\hline No & Pertanyaan & SS & $\mathbf{S}$ & RG & TS & STS \\
\hline 1 & $\begin{array}{l}\text { Apakah } \\
\text { Aplikasi Job } \\
\text { Fair mudah } \\
\text { digunakan? }\end{array}$ & 3 & 1 & 1 & 0 & 0 \\
\hline 2 & $\begin{array}{l}\text { Apakah fitur } \\
\text { aplikasi Job } \\
\text { Fair mudah } \\
\text { dipahami? }\end{array}$ & 3 & 1 & 1 & 0 & 0 \\
\hline 3 & $\begin{array}{l}\text { Apakah } \\
\text { aplikasi Job } \\
\text { Fair } \\
\text { membantu } \\
\text { pekerjaan? }\end{array}$ & 4 & 1 & 0 & 0 & 0 \\
\hline
\end{tabular}




\begin{tabular}{|c|c|c|c|c|c|c|}
\hline 4 & $\begin{array}{l}\text { Apakah } \\
\text { aplikasi Job } \\
\text { Fair berjalan } \\
\text { dengan baik? }\end{array}$ & 3 & 1 & 1 & 0 & 0 \\
\hline 5 & $\begin{array}{l}\text { Apakah } \\
\text { Kecepatan } \\
\text { aplikasi Job } \\
\text { Fair terbilang } \\
\text { baik? }\end{array}$ & 1 & 2 & 1 & 1 & 0 \\
\hline & Total & \multicolumn{5}{|c|}{108} \\
\hline Rata-r: & $\begin{array}{l}\text { ta Total Skor } \\
\text { Likert }\end{array}$ & \multicolumn{5}{|c|}{0.864} \\
\hline $\begin{array}{r}\text { Rata-r: } \\
\text { Li }\end{array}$ & $\begin{array}{l}\text { ta Total Skor } \\
\text { kert }(\%)\end{array}$ & \multicolumn{5}{|c|}{$86.4 \%$} \\
\hline
\end{tabular}

Berdasarkan pengujian yang dilakukan didapatkan hasil total rata-rata skor likert 86.4 persen dihasilkan dari pertanyaan yang dijawab oleh responden maka dapat disimpulkan bahwa fitur yang terdapat pada aplikasi berfungsi dengan baik dan membantu kandidat dalam melakukan proses rekrutmen, aplikasi yang dibuat mudah dalam penggunaannya serta kecepatan akses aplikasi yang baik. Aplikasi yang dibangun berjalan dengan baik dan dapat membantu pekerjaan staf HCD dalam melaksanakan proses rekrutmen di berbagai daerah

\section{Simpulan}

Berdasarkan penelitian dan pengujian yang dilakukan maka dapat disimpulkan bahwa aplikasi Job Fair membantu proses perekrutan karyawan karena melalui aplikasi ini user dapat memperoleh data seputar karyawan yang digunakan sebagai acuan untuk mendapatkan karyawan yang sesuai dengan kebutuhan perusahaan yang dapat dilakukan secara online. Penelitian ini dapat dikembangkan pada beberapa aspek, antara lain : desain user interface dan user experienc, mengoptimalkan aplikasi supaya pada saat aplikasi berjalan proses load data lebih cepat serta penambahan fitur seperti contact us yang memfasilitasi kandidat untuk berinteraksi dengan staf HRD apabila terjadi kendala pada proses input data.

\section{Daftar Pustaka}

[1] D. A. Permana dan D. R. Yudhi, "Analisis Dan Perancangan Sistem Informasi Perekrutan Karyawan Berbasis Web ( Studi pada PT Sumber Abadi Bersama, Gondanglegi , Kabupaten Malang )," Jurnal Administrasi Bisnis vol. 56, no. 1, hal. 20-28, 2018.

[2] Hendri dan A. Y. Permata, "Analisis dan Perancangan Sistem Informasi Perekrutan Karyawan Berbasis Web," Simposium Nasional Ilmu Pengetahuan dan Teknologi (SIMNASIPTEK) 2017, hal. 235-239.

[3] R. Harminingtyas, "Analisis Layanan Website Sebagai Media Promosi, 
Media Transaksi dan Pengaruhnya Terhadap Brand Image Perusahaan pada Hotel Ciputra di Kota Semarang", Jurnal STIE Semarang vol. 6, no. 3, hal. 37-57, 2014.

[4] P. Marsha, "Rekrutmen Karyawan: Definisi, Tujuan, Proses dan Sistem Rekrutmen," 2009. [Daring]. Tersedia pada: https://www.psikologindonesia.co.id/2019/11/rekrutmen-karyawandefinisi-tujuan.html

[5] H. W. Saputro, "Pengertian Website, Web Hosting Dan Domain Name," 2019. [Daring]. Tersedia pada: https://www.boc.web.id/pengertian-websitewebhosting-domainname/.

[6] L. Trisnawati dan E. Syafrizal, "Rancangan Sistem Rekrutmen Karyawan Berbasis Web pada PT. fast Food Indonesia Region Pekanbaru", Jurnal Teknologi dan Sistem Informasi UNIVRAB vol. 1, no. 1, hal. 25-30, 2016.

[7] A. B. Yanto, A. Fauzi, dan F. A. Jariyah, "Sistem Informasi E-Recruitment Karyawan Berbasis Web pada PT Jasa Swadaya Utama (Jayatama)", Jurnal Teknologi Informatika dan Komputer, vol. 4, no. 2, hal. 1-6, 2018.

[8] W. J. Darungo dan A. R. Tanaamah, "Facultative Inward Application Design Using Pega Platform At PT. Sinarmas Insurance", ITSMART: Jurnal Teknologi dan Informasi, vol. 7, no. 1, hal. 37-43, 2018.

[9] S. Arnold, “Apa itu Agile?”, 2019. [Daring]. Tersedia pada: https://sprout.co.id/id/apa-itu-agile/.

[10] V. Sawant, "What is Pega", 2014. [Daring]. Tersedia pada: https://coderanch.com/t/93084/open-source/PEGA.

[11] A. A. Pradipta, Y. A. Prasetyo, dan N. Ambarsari, "Pengembangan Web ECommerce Bojana Sari Menggunakan Metode Prototype", e-Proceeding of Engineering, vol. 2, no. 1, hal. 1042-1056, 2015.

[12] R. Rachmawati, D. Kusumastuti, dan N. Susanti, "Pembelajaran Soft Skill Berbasis Pada Hasil Pemetaan Personality Lulusan Universitas Widyatama dengan Pendekatan Metode DISC (Dominance, Influence, Steadiness dan Compliance)", Conference on Management and Behavioral Studies, hal. 348-357, 2016.

[13] Nur'aeni, “Tes Psikologi: Tes Inteligensi dan Tes Bakat", Universitas Muhammadiyah (UM) Purwokerto Press, hal. 173, 2012.

[14] R. Jiandy, Y. W. Wiratama, dan S. Hansun, "Implementation of C4.5 and PAPI Kostick to Predict Students Potential as Organization Caretaker", International Journal of Information Technology, Computer Science and Open Source, vol. 1, no. 1, hal. 1-8, 2017. 